

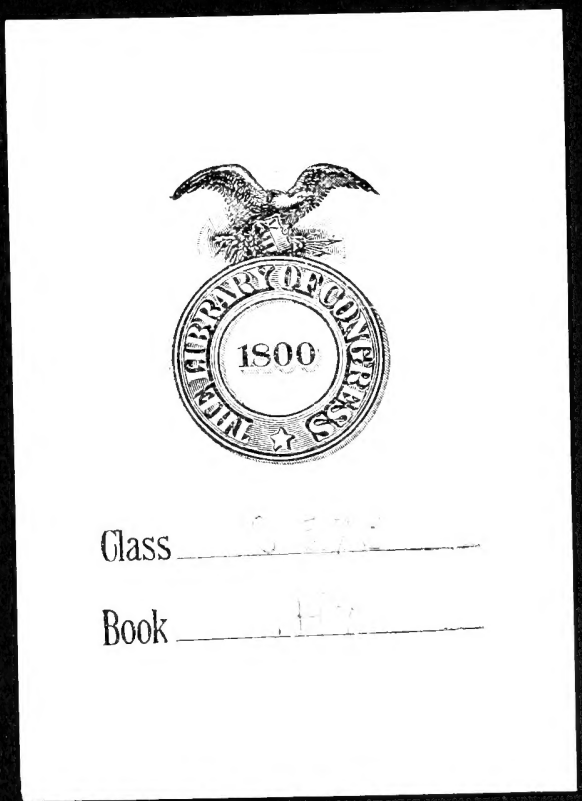

Book 


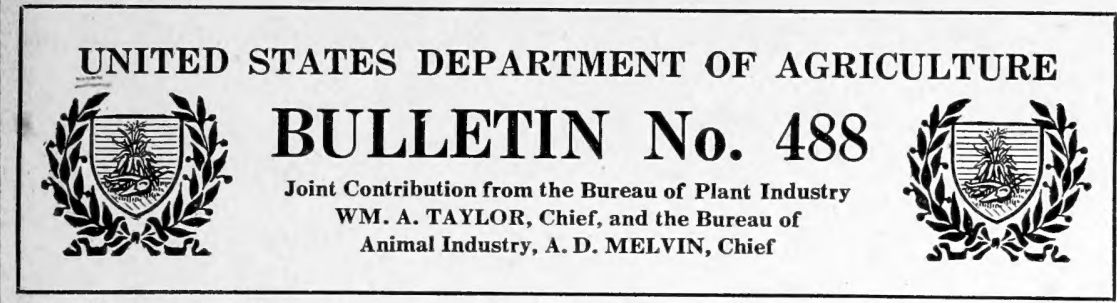

Washington, D. C.

$\boldsymbol{\Delta}$

February 26, 1917

\section{EXPERIMENTS IN THE DISPOSAL OF IRRIGATED CROPS THROUGH THE USE OF HOGS. ${ }^{1}$}

By James A. Holden, Assistant, Office of Western Irrigation Agriculture. In cooperation with the Bureau of Animal Industry.

\begin{tabular}{|c|c|c|c|}
\hline & CONT & ENTS. & \\
\hline & Page. & & Page. \\
\hline $\begin{array}{l}\text { uction ......................................... } \\
\text { l description of the methods followed.. }\end{array}$ & 1 & Alfalfa pasturing experiments-Continued. & \\
\hline lfalfa pasturing experiments ............... & 2 & Alfalfa pasture for sows and litters...... & 16 \\
\hline $\begin{array}{l}\text { Alfalfa pasture supplemented with a } 2 \text { per } \\
\text { cent ration of corn.................... }\end{array}$ & 3 & 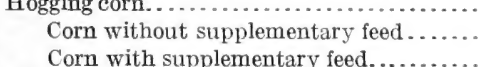 & $\begin{array}{l}19 \\
19 \\
21\end{array}$ \\
\hline $\begin{array}{l}\text { Alfalfa pasture with various grain supple- } \\
\text { ments.................................. }\end{array}$ & 7 & 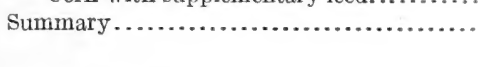 & 24 \\
\hline
\end{tabular}

\section{INTRODUCTION.}

The farmer who makes a success on high-priced irrigated land must not only grow large crops, but he must market these crops in the most advantageous way. Most crops grown in localities far removed from the large consuming centers should be marketed in condensed form, so as to reduce the cost of transportation. For example, a hundred pounds of butter can be shipped to market much more cheaply than the hay and grain required to produce this butter. The farmer should take advantage of this fact in organizing his operations. In addition to this saving, the manure resulting from the feeding of the crops makes it possible to produce larger crops in subsequent years.

1 The experiments reported in this bulletin have been conducted on the Scottsbluff Experiment Farm on the North Platta Irrigation Project in Nebraska. This experiment farm is conducted by the United States Department of Agriculture in cooperation with the State Experiment Station of Nebraska. The primary object of these experiments has been to determine the most efficient method of utilizing alfalfa, which is the most important crop on this project, as it is on nearly all of the irrigated projects of the West. The author desires to acknowledge the assistance given him by Mr. Henry Sullivan in carrying out the details of the experiments.-C. S. Scofield, Agriculturist in Charge, 0 ffice of Western Irrigation. Agriculture. $65731^{\circ}-$ Bull. $488-17-1$ 
Many of the farmers on irrigated projects are financially unable at present to secure dairy cows or to get cattle or sheep to feed. There are very few, however, who can not get into the hog business in a very short time. Less capital and time are required in getting into the hog business than in any other live-stock industry. With $\$ 25$ with which to buy small pigs and with very little grain and good alfalfa pasture, the farmer can get well started in the hog business in two years. Horses and cattle increase annually 60 to 80 per cent, sheep a little more than 100 per cent, while hogs should increase 600 per cent or better. The buildings necessary for the housing of hogs are also relatively inexpensive. The hog is a very economical feeder. It takes less feed to produce a pound of pork than any other kind of meat produced on the farm. The hog has the ability quickly to transform the products of the farm into a readily marketable commodity.

In the irrigated sections of the West, where alfalfa is the principal crop and where grain crops occupy a secondary position, the farmer needs information on the following points: (1) The practicability of using alfalfa as hog pasture; (2) the value of different quantities of grain when fed to hogs on alfalfa pasture; (3) the comparative values of corn and ground barley when fed to hogs on alfalfa pasture; and (4) the practicability of hogging down corn.

In order to secure information on these points, experiments were inaugurated at the Scottsbluff Experiment Farm on the North Platte Reclamation Project in 1912 and continued with some modifications in 1913, 1914, and 1915. The results of these experiments are reported in this bulletin.

\section{GENERAL DESCRIPTION OF THE METHODS FOLLOWED.}

It has been the aim in this bulletin to use average prices and to report sufficient fundamental data to enable anyone to apply different prices to the results. The prices used, except where otherwise stated, are as follows: Gains made by hogs, $\$ 7$ per hundredweight; corn, $\$ 1.07$ per hundredweight (or 60 cents a bushel); ground barley, $\$ 1$ per hundredweight; alfalfa hay, $\$ 8$ a ton; tankage, $\$ 64$ a ton. The data, which usually have been calculated to an acre basis, show the results that were obtained from quarter-acre plats of alfalfa pasture, which, if cut for hay, would have yielded from 4 to 6 tons per acre; and in the case of corn hogged, from one-third or one-quarter acre plats that yield as high as 80 bushels of corn per acre. It must be remembered by farmers who attempt to follow these methods of crop utilization that the higher the yield of the crop the larger will be the returns.

The term "per cent," when referring to rations, indicates the number of pounds fed daily per 100 pounds of live weight. The cost of 
the condiments fed, sprays used, interest on investment, risk, and labor are not considered in this report. The term "net return," as used in the following text and tables, refers to the difference between the total return and the estimated value of grain fed and is not to be taken as the net return of the land after production costs and interest charges have been deducted.

The hogs in these experiments had access to salt, slacked coal, and rock phosphate most of the time. They were also sprayed with coal-tar creosote every two or three weeks to keep them free from lice. In fact, they received the treatment that every farmer should give his hogs. The hog usually receives the least care and consideration of any farm animal. It is commonly believed that anything is good enough for hogs, but, on the contrary, the hog will respond as much to good care and treatment as any kind of live stock. Regularity in feeding, both in time and quantity of feed, clean quarters, and freedom from lice are three very important factors that are essential to successful hog raising; and these were provided in the experiments under consideration. The data here reported are the results of tests covering one to four years. In the alfalfa pasturing experiment, two lots of hogs were used each season, and in the corn hogging experiment, with supplemental feeds, duplicate lots were used.

\section{ALFALFA PASTURING EXPERIMENTS.}

\section{alfalfa Pasture supplemented with a 2 PER Cent Ra'́ton OF CORN.}

The alfalfa pasturing experiments were begun in 1913 and continued in 1914 and 1915. Each year a quarter-acre plat was used. The plat was divided into two equal parts and the hogs were changed from one to the other as the pasture became short. This allowed the alfalfa to recuperate and at the same time provided fresh, palatable feed. It was the plan to pasture the alfalfa to its full carrying capacity but not to overgraze. This made it necessary to remove some of the hogs during the latter part of the experiment, for as the season advanced and the nights became cool the alfalfa made slower growth and at the same time the hogs were increasing in size, thus requiring more feed. A few times during periods of three or four days of cloudy weather and also during the last month, when alfalfa was making little growth, the plats were perhaps slightly overpastured. As far as could be determined, however, no plat was pastured more heavily than another.

The corn was fed on the ear during the first period, and shelled corn was fed during the second period. Ear corn was fed on the ground and the shelled corn in a trough. The barley was ground and fed as a thick slop. Grain was fed once a day, in the evening. It is believed that when fed grain but once a day the hogs will make more 
use of the pasture than when grain is fed both morning and evening, as is usually the case. When not fed until evening, the hogs become hungry and will graze during the cool hours of the evening, even after the grain is eaten. Again, if the hogs are not fed grain in the morning they will stay out on pasture until the heat of the sun drives them to shade. The method of feeding grain once a day also saves labor.

During the pasturing season two sets of hogs were used. Fallfarrowed shotes were used during the first period and spring-farrowed pigs during the second period. In 1914 this plan was not followed strictly, as it was necessary to use a few fall-farrowed pigs

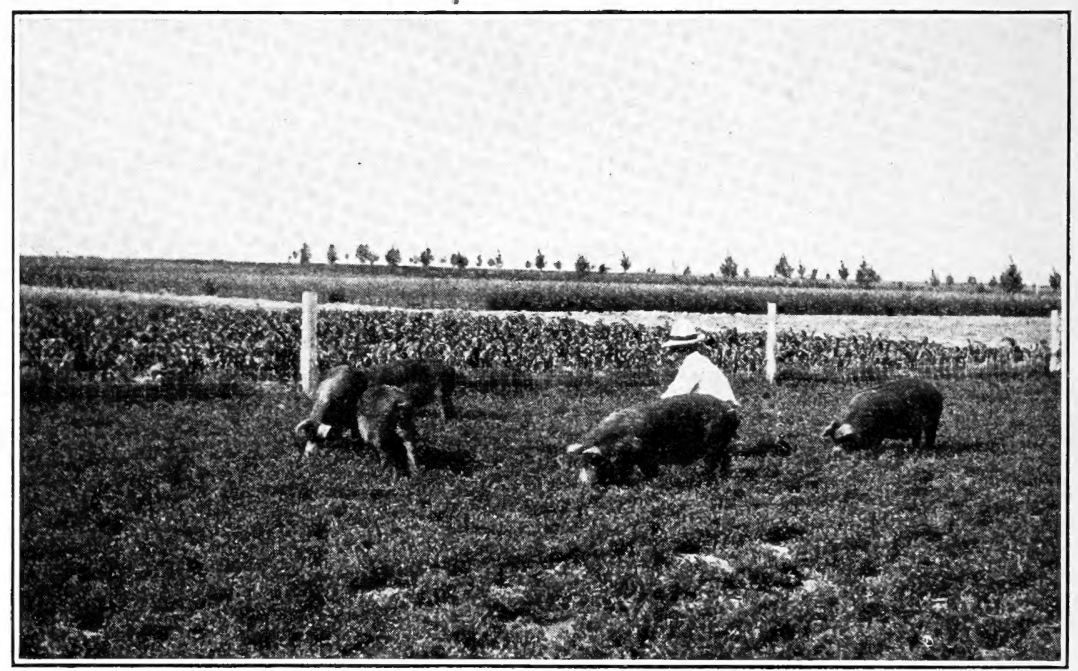

$4548 W 1$

Fig. 1.-Five fall-farrowed shotes on alfalfa pasture supplemented with a 2.3 per cent ration of corn during the first period in 1913 . These shotes in 61 days gained 381 pounds from one-fourth of an acre of alfalfa pasture and 1,047 pounds of corn.

throughout the season, owing to the loss of spring pigs from cholera. The reason for using two sets of hogs is that fall-farrowed pigs when fed a liberal grain ration are ready for market about July 15 , and April-farrowed pigs are not large enough to utilize the pasture much before that date.

EXPERIMENTS IN 1913.

Five thrifty fall-farrowed shotes, weighing a total of 544 pounds, were turned on a quarter-acre plat of second-year alfalfa on May 2. The five shotes were all the plat would carry. They were removed from the plat on July 2, when they weighed a total of 925 pounds, having gained 381 pounds during the 61 days they were on the plat. While on pasture these hogs were fed 1.047 pounds of corn, at the 
rate of approximately 2.3 pounds daily for each 100 pounds of live weight. Figure 1 shows the five shotes on alfalfa pasture.

On July 6, eight spring pigs, weighing a total of 273 pounds, were put on the alfalfa plat from which the previous lot had been removed. It was soon apparent that these eight pigs would not keep the pasture fed down, and on July 20 four more, weighing a total of 139 pounds, were added. All 12 pigs were unable to keep the pasture fed down during the early part of the period, so that it was necessary to clip the alfalfa once on each half of the plat. The 12 pigs were kept on this plat until September 10, when 6 were removed, the other 6 remaining until September 30. During September, however, the pasture made but little growth and the 6 pigs gained only 59 pounds during the 20-day period. While on the alfalfa pasture, the hogs gained a total of 697 pounds from the quarter-acre plat of alfalfa and 1,267 pounds of corn, the latter being fed at the rate of approximately 2.3 pounds daily for each 100 pounds of live weight.

The results secured in 1913 with these two lots of hogs on alfalfa pasture are summarized in Table I, in which the data have been calculated to an acre basis.

TABLE I.-Results obtained by feeding two lots of hogs on alfalfa pasture, supplemented with approximately a 2 per ecnt corn ration, at the scottsbluff Experiment Farm in 1913.

\begin{tabular}{|c|c|c|c|}
\hline Items of comparison. & $\begin{array}{c}\text { First } \\
\text { period. }\end{array}$ & $\begin{array}{l}\text { Second } \\
\text { period. }\end{array}$ & $\begin{array}{l}\text { Entire } \\
\text { season. }\end{array}$ \\
\hline 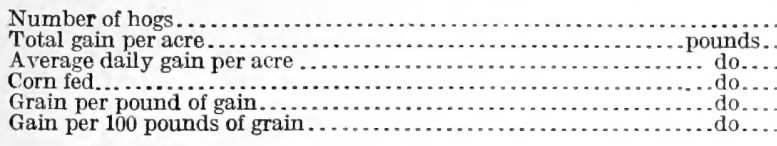 & $\begin{array}{r}20 \\
1,524 \\
24.8 \\
4,188 \\
2.75 \\
36.4\end{array}$ & $\begin{array}{r}48 \\
2,428 \\
25.2 \\
5,063 \\
2.09 \\
49.8\end{array}$ & $\begin{array}{r}3,952 \\
26.1 \\
9,256 \\
2.34 \\
42.7\end{array}$ \\
\hline 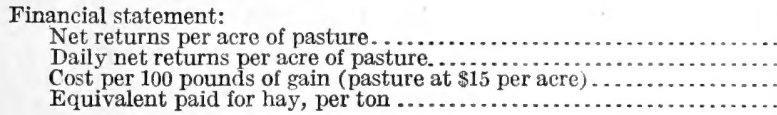 & $\begin{array}{r}\$ 61.88 \\
1.01 \\
3.25 \\
33.63\end{array}$ & $\begin{array}{r}\$ 115.72 \\
1.35 \\
2.64 \\
32.07\end{array}$ & $\begin{array}{r}\$ 177.60 \\
1.17 \\
2.88 \\
32.85\end{array}$ \\
\hline
\end{tabular}

A very important fact shown in Table $I$ is the large number of hogs carried per acre of alfalfa pasture. From May 1 to July 2 the carrying capacity of an acre was at the rate of 20 hogs with an average initial weight of 108.9 pounds, and from July 20 to September 10 the carrying capacity was at the rate of 48 hogs with an average initial weight of 39.8 pounds. The total final weight of the first lot was 3,700 pounds, whereas the total initial weight of the second lot was only 1,900 pounds. This shows that the smaller the hogs the less total live weight the pasture will carry; that is to say, twenty 25-pound pigs will require more pasture than an equal weight of 100 -pound shotes. 
From a farmer's standpoint a very significant fact shown in Table I is the high return per acre of alfalfa pasture after the value of the corn fed is deducted from the value of the gains. With the first lot this was $\$ 61.88$ and with the second lot $\$ 115.72$, or a total of $\$ 177.60$ per acre for the season. If it is assumed that the value of the labor necessary to care for the pigs is equal to the cost of harvesting the hay crop, the hogs paid an equivalent of $\$ 33.63$ a ton for the first cutting and $\$ 32.07$ a ton for the second and third cuttings. This estimate is based on the assumption that the pastured plat would have produced hay at the same rate as the average of 11 similar plats in the same field. On the North Platte project $\$ 6$ a ton in the stack is considered a good price for alfalfa hay. Considering these facts, the high value of hogs as a means of marketing alfalfa is clearly apparent. It required 2.75 pounds of corn for the first lot and 2.09 pounds for the second lot for each pound of gain made. With alfalfa pasture valued at $\$ 15$ per acre for the season ( $\$ 5$ for the first period and $\$ 10$ for the second) and corn at $\$ 1.07$ per hundredweight, each 100 pounds of gain in the first lot cost $\$ 3.25$ and in the second lot $\$ 2.64$, or an average of $\$ 2.88$ for the two lots. This emphasizes the value of alfalfa pasture as a hog feed.

AVERAGE OF THREE YEARS' RESULTS.

Substantially the same methods were followed in 1914 and 1915 as in 1913, as outlined above. Each year, fall-farrowed pigs were used in the first period and spring-farrowed pigs in the second period, except in 1914, when, because of losses from cholera, it was necessary to use fall pigs during the entire season. In 1915 there were two lots receiving the 2 per cent corn ration, so that during the three years there have been eight lots in all, four in each pasturing period. The results of the three years' tests with these eight lots are summarized in Table II, in which the data have been calculated to an acre basis.

TABLE II.-Results obtained by feeding eight lots of pigs on alfalfa pasture, supplemented with approximately a 2 per cent corn ration, at the Scottsbluff Experiment Farm in 1913, 1914, and 1915.

\begin{tabular}{|c|c|c|c|}
\hline Items of comparison. & $\begin{array}{c}\text { First } \\
\text { period. }\end{array}$ & $\begin{array}{l}\text { Second } \\
\text { period. }\end{array}$ & $\begin{array}{c}\text { Entire } \\
\text { season. }\end{array}$ \\
\hline 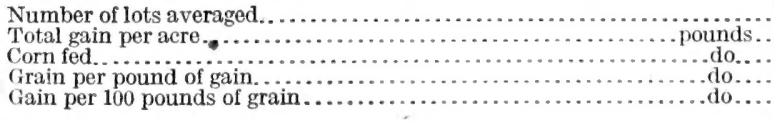 & $\begin{array}{l}1,271 \\
3,671 \\
2.85 \\
34.7\end{array}$ & $\begin{array}{r}1,910 \\
4,173 \\
2.18 \\
45.9 \\
\end{array}$ & $\begin{array}{r}8 \\
3,181 \\
7,844 \\
2.47 \\
40.5 \\
\end{array}$ \\
\hline 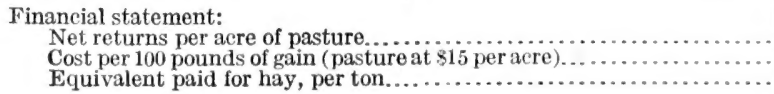 & $\begin{array}{r}\$ 49.70 \\
3.36 \\
22.19\end{array}$ & $\begin{array}{r}\$ 89.05 \\
2.86 \\
27.13\end{array}$ & $\begin{array}{r}\$ 138.75 \\
3.11 \\
25.13\end{array}$ \\
\hline
\end{tabular}


On an acre basis, the four lots made an average total gain of 1,271 pounds during the first period and 1,910 pounds during the second period, or a total of 3,181 pounds for the season. During the first period the hogs were fed 3,671 pounds of corn and during the second period 4,173 pounds, or a total of 7,844 pounds during the season. It required 2.88 pounds of corn in the first period and 2.18 pounds in the second period, in addition to the alfalfa pasture, to produce 1 pound of gain. For every 100 pounds of corn fed the hogs made a gain of 34.7 pounds during the first period and 45.9 pounds in the second period, or an average of 40.5 pounds during the season.

With hogs at $\$ 7$ per hundredweight and corn at $\$ 1.07$ per hundredweight the net return per acre of alfalfa pasture was $\$ 49.70$ for the first period and $\$ 89.05$ for the second period, or a total of $\$ 138.75$ for the season. This is equal to a daily net return of 90 cents an acre for the entire period of 154 days. If a charge of $\$ 5$ for the first period and $\$ 10$ for the second period is made for an acre of alfalfa pasture, the feed required to produce 100 pounds of gain cost $\$ 3.36$ during the first period, $\$ 2.86$ during the second period, and $\$ 3.11$ for the season.

Alfalfa plats similar to those pastured and in the same field have each year been harvested for hay. The three-year average yield of these plats was 5.52 tons per acre, or 2.24 tons for the first period and 3.28 tons for the second period of pasturing. On the basis of this yield, if it is assumed that the cost of caring for the hogs is equal to the cost of harvesting the hay, the hogs in the first period paid $\$ 22.19$ and in the second period $\$ 27.13$, or an average for the season of $\$ 25.13$ a ton for alfalfa hay.

\section{ALFALFA PASTURE WITH VARIOUS GRAIN SUPPLEMENTS.}

EXPERIMENTS IN 1914 .

In 1914 experiments were inaugurated to secure information regarding (1) the most economical quantity of corn to feed to hogs on alfalfa pasture, (2) the relative efficiency of 2 per cent corn and 2 per cent ground-barley rations as supplements to alfalfa pasture, and (3) the carrying capacity of alfalfa pasture when no supplement is fed.

The alfalfa pastured in these experiments was seeded on April 6, 1912, hay having been harvested from the plats during the seasons of 1912 and 1913 . The yields of the different plats during these years were very uniform. Figure 2 gives a view of the alfalfa pasture used in this experiment. The hogs used during the first period were a very inferior lot. They were a mixture of several breeds, ranging from high-grade Berkshires to scrubs and varying in size from 50 to 160 pounds. 
These hogs were put on alfalfa pasture, with a small ration of grain, for about a week after they were received at the farm. They were then weighed, ear tagged, and divided into lots which were as uniform as possible. The mean of three consecutive days' weighing was taken as the initial weight. Each hog was weighed separately and individual weights were kept of each throughout the experiment. Lot 1 received no grain; lot 2 received a 1 per cent ration of corn; lot 3 received 2 per cent corn; lot 4,2 per cent barley; and lot 5, 3 per cent corn.

Shortly after the beginning of the first period an outbreak of cholera occurred. Treatment was applied as soon as possible, but

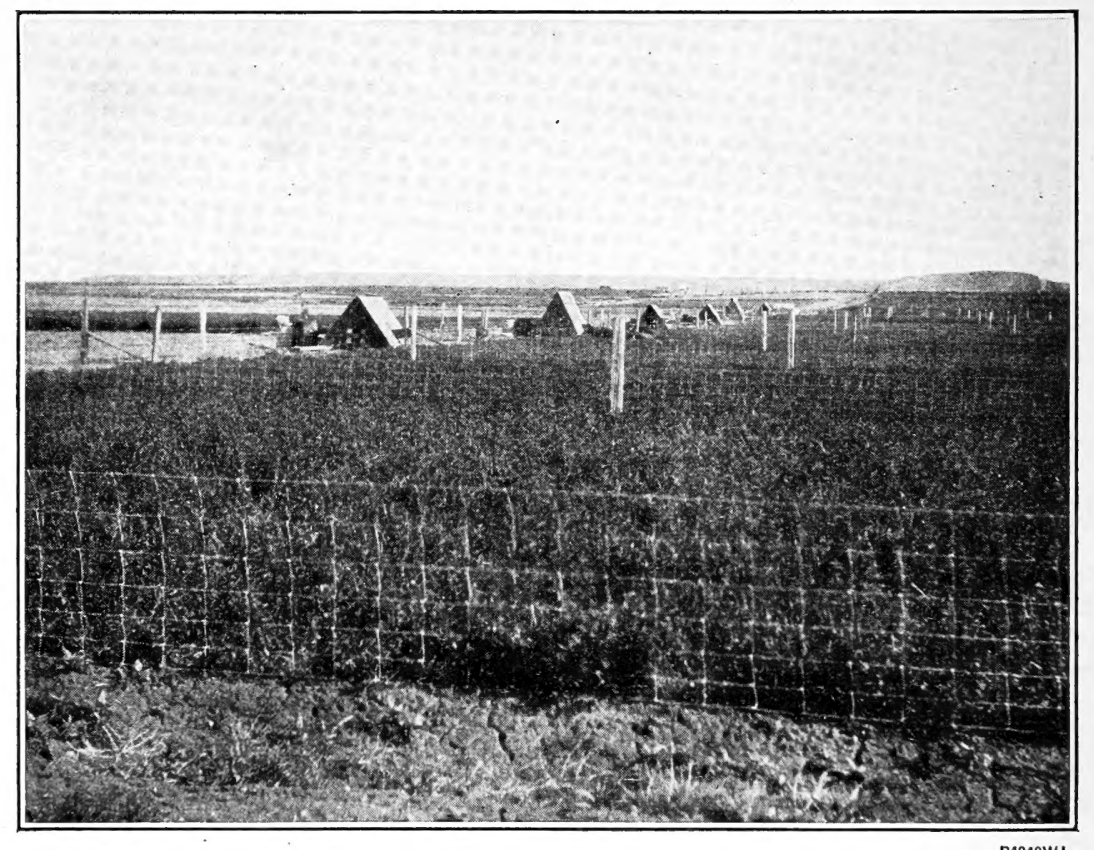

FIG. 2.-The alfalfa plats used in 1914 and 1915 in the hog-pasturing experiments at the Scottsbluff Experiment Farm, showing the portable houses and the method of dividing the pastures.

the disease did enough damage to affect the results of the test. Nevertheless, fair returns were secured, the net returns per acre of alfalfa pasture from May 3 to July 2 ranging from $\$ 18.76$, where no supplement was fed, to $\$ 54.19$, where the pasture was supplemented with a 3 per cent ration of corn.

The plan was to use spring-farrowed pigs during the second period of the experiment, but, as a great many of the spring pigs had died from cholera, it was necessary to select the best of the smaller hogs that had been used during the first period. No hogs, however, were used from the two lots which had had no grain and 1 per cent corn, 
respectively. The hogs used were good, thrifty stock, but were not uniform in size, varying from 15 to over 100 pounds in weight. The majority weighed about 45 pounds. They were divided into lots and turned on the alfalfa pasture on July 8. The results obtained in the first period showed that the hogs which were fed grain consumed less alfalfa than those which received no grain. For this reason the number of hogs in the lots in the second period was increased in accordance with the grain fed. The average weights of the hogs in the different lots were fairly uniform, at about 58 pounds. During the first two weeks of the period it was necessary to replace six pigs which developed cholera symptoms. Owing to these changes, the average initial weight per pig in lots 1 and 5 was somewhat higher than the average weight per pig in the other lots.

As the hogs were weighed only every 15 days, and as the grain ration was based on the initial weight at the beginning of each 15 -day period, with a gradual increase to cover the estimated daily gain, it is apparent that the hogs might be fed slightly more or less than the quantity planned, but the difference was small. At the end of the experiment the total amount of grain actually fed was ascertained to have been as follows: Lot 2 was fed 1.1 per cent corn; lot 3 was fed 2.06 per cent corn; lot 4 was fed 1.93 per cent ground barley; and lot 5 was fed 2.64 per cent corn. Lot 1 received no grain.

There were seven pigs, weighing a total of 396 pounds, in lot 1 at the beginning of the experiment. One pig died at the end of the second month, and on Angust 22, when the plat was becoming overpastured, a hog weighing 120 pounds was taken out. On September 9, when the growth of the alfalfa had become very slow, four more pigs were taken off the plat. The total gain made by the pigs in this lot from July 8 to October 6 was 102 pounds, or 408 pounds per acre. In lot 2 there were eight pigs, with a total initial weight of 516 pounds. On August 22 one pig weighing 119 pounds, and on September 9 five more pigs, weighing a total of 391 pounds, were remored because the pasture was becoming overgrazed. This lot made a total gain of 252 pourids from the quarter acre of alfalfa and 495 pounds of corn. In lot 3 , which was fed 2 per cent corn, there were 10 pigs, with a total initial weight of 573 pounds. On August 22 one pig, weighing 126 pounds, was taken out, and September 9 six more, weighing a total of 573 pounds, were removed, leaving three pigs with a combined weight of 305 pounds. This lot was fed 1,162 pounds of corn and made a total gain of 475 pounds. In lot 4 , which was fed 2 per cent barley, there were 10 pigs, having a total initial weight of 561 pounds. To avoid overpasturing the plat, one pig, weighing 92 pounds, was removed on August 22, and six pigs, weighing a total of 439 pounds, were removed on September 9. This lot was fed 1,058 pounds of $65731^{\circ}-$ Bull. 48S-17- 2 
barley during the period and made 435 pounds of gain. In lot 5 , which was fed 3 per cent corn, there were 11 pigs, having a total initial weight of 771 pounds. Owing to shortage of pasture, one pig weighing 135 pounds was removed August 22. On September 9 six more pigs, with a total weight of 589 pounds, were removed. Lot 5 was fed 2,202 pounds of corn during the period and made a total gain of 735 pounds. The experiment closed on October 6 .

Table III shows the combined results of the two periods of 1914, calculaterl to an acre basis. The results for the first period were not what could be expected under favorable conditions, since the hogs used were rather inferior and the outbreak of cholera did some damage. The hogs used during the second period were fairly good stock and the results should be fairly dependable. It is thought also that the combined results of the two periods give a reliable indication of the effects of feeding different quantities of grain, as well as showing what was possible under the conditions that prevailed.

TABLE III_-Results obtained by feeding five lots of hogs on alfalfa pasture, supplemented with varying quantities of grain, at the Scottsbluff Experiment Farm during two periods in 1914.

\begin{tabular}{|c|c|c|c|c|c|}
\hline Items of comparison. & $\begin{array}{c}\text { Lot } 1, \text { no } \\
\text { grain. }\end{array}$ & $\begin{array}{l}\text { Lot } 2,1 \\
\text { per cent } \\
\text { corn. }\end{array}$ & $\begin{array}{l}\text { Lot } 3,2 \\
\text { per cent } \\
\text { corn. }\end{array}$ & $\begin{array}{l}\text { Lot 4, } 2 \\
\text { per cent } \\
\text { barley. }\end{array}$ & $\begin{array}{c}\text { Lot 5, } 3 \\
\text { per cent } \\
\text { corn. }\end{array}$ \\
\hline 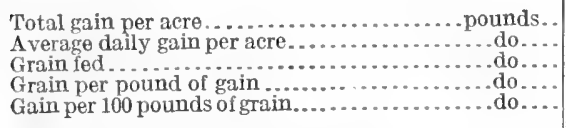 & $\begin{array}{r}676 \\
4.33 \\
\text { None. } \\
\hdashline\end{array}$ & $\begin{array}{l}1,520 \\
9.75 \\
3,595 \\
2.36 \\
42.3 \\
\end{array}$ & $\begin{array}{l}3,036 \\
19.46 \\
8,266 \\
2.72 \\
36.8 \\
\end{array}$ & $\begin{array}{l}2,780 \\
17.82 \\
7,744 \\
2.78 \\
36.0 \\
\end{array}$ & $\begin{array}{r}4,416 \\
28.30 \\
13,352 \\
3.02 \\
33.1 \\
\end{array}$ \\
\hline 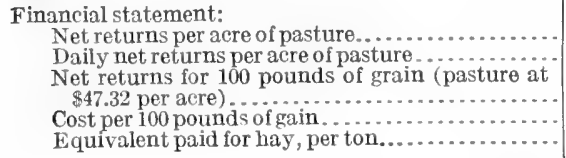 & $\begin{array}{r}\$ 47.32 \\
.30\end{array}$ & $\begin{array}{r}\$ 67.93 \\
.43 \\
1.64 \\
3.52 \\
13.38\end{array}$ & $\begin{array}{r}\$ 124.07 \\
.81 \\
2.00 \\
3.41 \\
19.21\end{array}$ & $\begin{array}{r}\$ 117.16 \\
.75 \\
1.91 \\
3.32 \\
17.86\end{array}$ & $\begin{array}{r}\$ 166.25 \\
1.06 \\
1.96 \\
3.61 \\
25.30\end{array}$ \\
\hline
\end{tabular}

Table III shows the total and daily gains for each lot of hogs from May 3 to October 6, a period of 156 days. The gains raried with the amount of grain ferl. Lot 1 made 676 pounds of gain; lot 2, 1,520 pounds; lot 3, 3,036 pounds; lot 4, 2,780 pounds; and lot 5, 4,416 pounds. The daily gains per acre as shown in Table III varied from 4.33 pounds in lot 1 , which received no grain, to 28.3 pounds in lot 5 , which received approximately a 3 per cent ration of corn. Lot 5 made 3,740 pounds more gain per acre than lot 1 . Lot 5 was fed 13,352 pounds of corn, while lot 1 received no grain. The 3,750 pounds of gain, therefore, can be credited to the use of 13,352 pominds of corn; that is to say, each 100 pounds of corn fed resulted in the production of 28 pounds of pork, wherens when hogs are fed corn alone 18 pounds per 100 pounds of corn is considered a satisfactory gain. The hogs in lot 5 paid $\$ 1.96$ per hundredweight for 
the corn fed. By this method of calculation it can be shown that lot 2 paid $\$ 1.64$, lot $3, \$ 2$, and lot $4, \$ 1.91$ per hundredweight for the grain fed.

The quantity of grain required with alfalfa pasture to produce a pound of pork varied from 2.36 pounds in lot 2 to 3.02 pounds in lot 5 , the quantity increasing with the total quantity of grain fed. The cost per 100 pounds of gain raried from $\$ 2.22$ in lot 1 to $\$ 3.61$ in lot 5. The total and daily net return per acre of alfalfa pasture increased with the amount of grain fed. Lot 1, with no grain, paid $\$ 47.32$ an acre for the alfalfa pasture. This was much more than the hay crop would have sold for in the stack had it been harvested. This partly explains why many farmers are content to carry hogs through the summer on alfalfa pasture with little or no grain. After paying for the grain fed, lot 2 paid $\$ 67.93$; lot $3, \$ 124.07$; lot 4 , $\$ 117.16$; and lot $5, \$ 166.25$ per acre of alfalfa pasture for the season. The daily net returns per acre of alfalfa increased from 30 cents where no grain was fed to $\$ 1.06$ where about 3 per cent of corn was fed.

Five plats of alfalfa in the same field where these experiments were conducted yielded at the rate of 6.56 tons of hay per acre in four cuttings. On the basis of this yield, if the cost of harvesting the hay crop is equal to the cost of caring for the hogs, lot 1 paid $\$ 7.22$ a ton for alfalfa hay; lot 2 paid $\$ 13.38$; lot $3, \$ 19.21$; lot $4, \$ 17.86$; and lot $5, \$ 25.30$. The manure left on the land is also of some value and should be considered in favor of the practice of pasturing hogs on alfalfa.

EXPERIMENTS IN 1915.

The 1914 pasturing experiments were repeated during the summer of 1915 , with the addition of one more lot $(3 \alpha)$ fed 2 per cent corn. These pasturing experiments were conducted on the same alfalfa plats that were used in 1914, with the exception of one, lot $3 a$, which was on third-year alfalfa. The same general plan was followed in 1915 as in 1914, as described above.

The 1915 season was very backward and suffered many disadvantages. The hogs were put on pasture on April 26. The first two weeks the hogs did well, but on May 18 a foot of snow fell and the temperature dropped to $29^{\circ} \mathrm{F}$. This made it necessary to remove the hogs from the plats for seven days, ciuring which time each lot was kept separately and fed the regular amount of grain. Again, on August 6, a severe hailstorm did a great deal of damage to the alfalfa. The damage done on the pasture plats was not as great as on the plats which were left for hay. There is little doubt that the hogs obtained more feed from the pastured plats than was harvested 
from the others. In 1914 the average yield from the harvested plats was 6.53 tons and in 1915 only 4.47 tons per acre. The hogs used in the experiments during 1015 were of very much better quality than those used in 1914. This may explain why the returns in 1915, notwithstanding the damage done to the alfalfa, were equal to those of 1914.

The first period extended from April 26 to June 30, or a total of 60 days. The shotes used were farrowed during the fall and late summer of the previous year and weighed an average of 108 pounds when the experiment began. The pigs used during the second period, which began June 30, were pure-bred Duroc-Jerseys. They were reared on the experiment farm, where they were farrowed during April and the early part of May. They weighed an average of 33 pounds when the experiment began. Though small, they were in good, thrifty condition. When the cool weather of autumn came on, the alfalfa made less growth, which made it necessary to take out hogs at different times. The experiment closed September 27.

Notwithstanding the fact that the summer of 1915 was very backward and cool, the returns from alfalfa pastures were practically the same as in 1914. The hogs used in 1915 were smaller and a very much better class of stock than those used in 1914, when returns from the first period were reduced by cholera. Better stock and freedom from sickness in 1915 apparently offset the low yield of alfalfa in that year. The second period in 1915 gave higher returns for both grain and pasture, and also cheaper gains than were secured in the first period. It is generally true that the smaller the hogs, other things being equal, the more economical the gains.

A summary of the results of the two periods of 1915 is given in Table IV, in which the data have been calculated to an acre basis.

Table IV.-Results obtained by feeding six lots of hogs on alfalfa pasture. supplemented with varying quantities of grain, at the Scottsbluff Experiment Farm during two periods in 1915.

\begin{tabular}{|c|c|c|c|c|c|c|}
\hline Items of comparison. & $\begin{array}{l}\text { Lot } 1, \text { no } \\
\text { grain. }\end{array}$ & $\begin{array}{l}\text { Lot } 2,1 \\
\text { per cent } \\
\text { corn. }\end{array}$ & $\begin{array}{c}\text { Lot } 3,2 \\
\text { per cent } \\
\text { com. }\end{array}$ & $\begin{array}{c}\text { Lot } 3 a, 2 \\
\text { per cent } \\
\text { corn. }\end{array}$ & $\begin{array}{l}\text { Lot } 4,2 \\
\text { per cent } \\
\text { barley. }\end{array}$ & $\begin{array}{c}\text { Lot } 5,3 \\
\text { per cent } \\
\text { corn. }\end{array}$ \\
\hline $\begin{array}{l}\text { Total gain per acre............. pounds. } \\
\text { Average daily gain per acre........ do... } \\
\text { Grain fed ........ } \\
\text { Grain per pound of gain.............. do.... } \\
\text { Gain per } 100 \text { pounds of grain........ do... }\end{array}$ & $\begin{array}{r}612 \\
4.0 \\
\text { None. } \\
\ldots . . . .\end{array}$ & $\begin{array}{r}1,456 \\
9.5 \\
2,752 \\
1.89 \\
53.0 \\
\end{array}$ & $\begin{array}{r}2,976 \\
19.3 \\
7,048 \\
2.53 \\
39.5 \\
\end{array}$ & $\begin{array}{r}2,760 \\
17.9 \\
6,796 \\
2.46 \\
40.7 \\
\end{array}$ & $\begin{array}{r}2,772 \\
18.0 \\
6,728 \\
2.43 \\
41.1 \\
\end{array}$ & $\begin{array}{r}4.292 \\
27.9 \\
12,168 \\
2.83 \\
35.3 \\
\end{array}$ \\
\hline 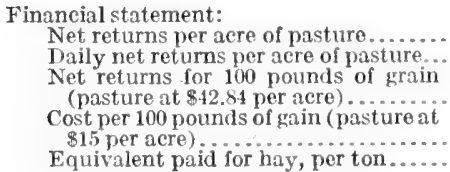 & $\begin{array}{r}\$ 42.84 \\
.28\end{array}$ & $\begin{array}{r}\$ 72.48 \\
.47 \\
2.14 \\
3.06 \\
16.21\end{array}$ & $\begin{array}{r}\$ 132.91 \\
.86 \\
2.20 \\
3.04 \\
29.54\end{array}$ & $\begin{array}{r}\$ 120.49 \\
.78 \\
2.21 \\
3.17 \\
26.95\end{array}$ & $\begin{array}{r}\$ 126.76 \\
.82 \\
2.23 \\
2.97 \\
28.13\end{array}$ & $\begin{array}{r}\$ 170.24 \\
1.10 \\
2.11 \\
3.38 \\
38.07\end{array}$ \\
\hline
\end{tabular}


For the entire season of 1915 , as shown in Table IV, the gains per acre were as follows: Lot 1,612 ; lot $2,1,456$; lot $3,2,976$; lot $3 a$, 2,760 ; lot 4, 2,772; and lot 5, 4,292 pounds. The lot that was fed 3 per cent corn made seven times as much gain as the lot which received no grain. The grain consumed for each pound of gain increased with the grain ration. It required 1.5 times as much grain for each pound of gain where a 3 per cent corn ration was fed as it did where only. a 1 per cent corn ration was fed. For every 100 pounds of grain fed the 1 per cent corn lots gained 53 pounds; the average of the 2 per cent grain lots was 40.4 pounds; and the 3 per cent corn lots gained 35.3 pounds.

When the gains made are figured at $\$ 7$ per hundredweight and the lots charged $\$ 1.07$ per hundredweight for corn and $\$ 1$ for ground barley, the net returns per acre for alfalfa pasture were as follows: Lot $1, \$ 42.84$; lot $2, \$ 72.48$; lot $3, \$ 132.91$; lot $3 a, \$ 120.49$; lot 4 , $\$ 126.76$; and lot 5, $\$ 170.24$. From April 26 to September 27 , a period of 154 days, the hogs gave an average daily net return ranging from 28 cents, where no grain was fed, to $\$ 1.10$, where 3 per cent corn was fed. At this rate a 10-acre alfalfa field pastured with hogs getting a 3 per cent ration of corn would pay $\$ 11$ net per day, whereas if no grain was fed the same 10 -acre field would return only $\$ 2.80$ per diay. The no-grain lot paid at the rate of $\$ 42.84$ an acre for alfalfa pasture. When the grain-fed lots are charged the same amount for the pasture, they still paid very liberally for the grain fed, as is shown in Table IV.

The equivalent paid for hay by the different lots greatly increased with the grain ration. The no-grain lot returned an equivalent of $\$ 9.58$; the 1 per cent lot, $\$ 16.21$; the average of the 2 per cent grain lots, $\$ 28.21$; and the 3 per cent grain lot paid $\$ 38.07$ per ton, or four times as much as the no-grain lot. This fact, together with the high price paid for the grain, emphasizes the advisability of feeding grain in connection with alfalfa pasture in order to realize the highest return from both the grain and the alfalfa crops.

SUMMARY OF THE TWO YEARS' RESULTS.

The results of the experiments in 1914 and 1915 with alfalfa pasture and various grain supplements are summarized in Table V. As two lots of hogs were used each year in each part of the test, the figures in Table $V$ show the average of the results secured from four lots of hogs in each instance. The figures have been calculated to an acre basis.

The results of two years' work show that hogs on alfalfa pasture without grain produced an average of $6+4$ pounds of gain per acre. The same area of pasture, with the addition of $3,17 \pm$ pounds of corn, 
produced 1,488 pounds of gain. Where 7,657 pounds of corn was fed the gain was 3,006 pounds; where 7,236 pounds of ground barley was fed the gain was $2, \pi 76$ pounds, and where 12,760 pounds of corn supplemented the alfalfa pasture, the gain was $4,3 \check{4} 4$ pounds per acre of pasture. With this information the farmer can apply prices that suit his own particular condition and determine the most economical quantity of grain to feed.

TABLE V.-Results obtaincl by fecding hogs on alfalfa pasture, supplemented with varying quantities of grain, at the S'cottsbluff Lixperiment Farm in 1914 and 1915.

\begin{tabular}{|c|c|c|c|c|c|}
\hline Items of comparison. & $\begin{array}{l}\text { Lot 1, } \\
\text { no } \\
\text { grain. }\end{array}$ & $\begin{array}{l}\text { Lot } 2,1 \\
\text { per cent } \\
\text { corn. }\end{array}$ & $\begin{array}{c}\text { Lot } 3,2 \\
\text { per cent } \\
\text { corn. }\end{array}$ & $\begin{array}{l}\text { Lot } 4,2 \\
\text { per cent } \\
\text { barley. }\end{array}$ & $\begin{array}{l}\text { Lot } 5,3 \\
\text { per cent } \\
\text { corn. }\end{array}$ \\
\hline 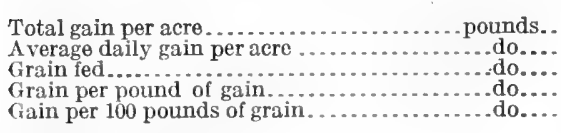 & $\begin{array}{l}644 \\
4.1\end{array}$ & $\begin{array}{r}1,488 \\
9.6 \\
3,174 \\
2.11 \\
47.4\end{array}$ & $\begin{array}{l}3,006 \\
19.3 \\
7,657 \\
2.63 \\
38.0\end{array}$ & $\begin{array}{l}2,776 \\
17.9 \\
7,236 \\
2.61 \\
38.3\end{array}$ & $\begin{array}{r}4,354 \\
25.0 \\
12,760 \\
2.93 \\
34.1\end{array}$ \\
\hline 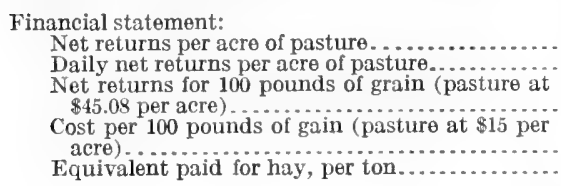 & $\begin{array}{r}\$ 45.08 \\
.29\end{array}$ & $\begin{array}{r}\$ 70.20 \\
.45 \\
1.86 \\
3.29 \\
12.71\end{array}$ & $\begin{array}{r}\$ 128.49 \\
.83 \\
2.16 \\
3.22 \\
23.25\end{array}$ & $\begin{array}{r}\$ 121.96 \\
.79 \\
2.06 \\
3.14 \\
22.10\end{array}$ & $\begin{array}{r}\$ 168.25 \\
1.08 \\
2.03 \\
3.48 \\
30.48\end{array}$ \\
\hline
\end{tabular}

Two years' results show that more pasture is required when no grain is fed and that as the grain ration is increased the area of pasture required is decreased. The areas required when no grain, 1 per cent grain, 2 per cent grain, and 3 per cent grain were fed were approximately as $5,4,3$, and 2 , respectively.

For every 100 pounds of grain fed, lot 2 made 47.4 pounds of gain; lot 3, 38 pounds; lot 4, 38.3 pounds; and lot $5,34.1$ pounds. The higher the grain ration the lower the gains per unit of grain fed. Also, the lower the grain ration the more pasture was required for 100 pounds of gain.

With the prices here used, the two-year average net return per acre of alfalfa pasture were as follows: No-grain lot, $\$ 45.08 ; 1$ per cent corn lot, $\$ 70.20 ; 2$ per cent corn lot, $\$ 128.49 ; 2$ per cent ground barley lot, $\$ 121.96$; and the 3 per cent corn lot, $\$ 168.25$. The arerage daily net return per acre for 154 days ranged from 29 cents, where no grain was fed, to $\$ 1.08$, when a 3 per cent ration of corn was fed.

The two-year average net return per acre of alfalfa pasture from lots 3 and 4 show the sum of $\$ 6.43$ in favor of corn over ground barley. It will also be seen from Table $V$ that the corn lot was fed a little more grain than the barley lot. Higher returns would, therefore, be expected from the corn-fed lot, as the results have shown that the net returns for pasture increase with the grain ration. The difference in net returns, therefore, is not enough to warrant the state- 
ment that corn at $\$ 1.07$ per hundredweight is cheaper feed than ground barley at $\$ 1$ per hundredweight. The average of the two years' results, and especially the 1915 results, seems to indicate very strongly that, pound for pound, ground barley is approximately equal to corn as feed for hogs in supplementing alfalfa pasture.

The two-year average net return for alfalfa pasture was $\$ 45.08$ where no grain was fed. If the grain-fed lots are charged this amount for pasture, the net returns for each 100 pounds of grain fed were as follows: 1 per cent corn lot, $\$ 1.86 ; 2$ per cent corn lot, $\$ 2.16$; 2 per cent barley lot, $\$ 2.06$; and the 3 per cent corn lot, $\$ 2.03$. It appears from this that 2 pounds of corn per day for each 100 pounds of live weight is the most satisfactory ration of corn for hogs

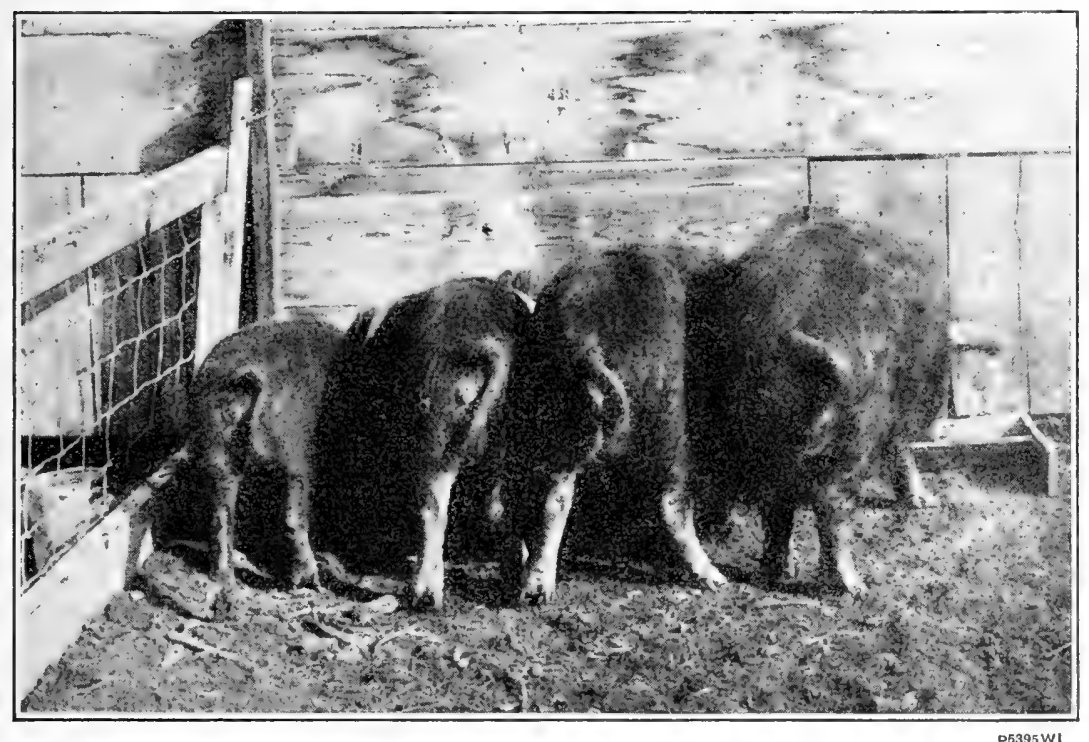

FIG. 3.-Representative hogs from the lots fed varying grain supplements on alfalfa pasture at the close of the second period in 1914. From left to right: No grain, 1 per cent corn, 2 per cent corn, and 3 per cent corn.

on alfalfa pasture in order to get the highest return from both the corn and alfalfa pasture. This is true when the feeder can get only a limited amount of corn, but when an abundant supply of corn is available at not more than $\$ 1.07$ per hundredweight, it may be desirable to feed about 3 pounds of corn to each 100 pounds of live weight. Hogs fed a 3 per cent ration of corn will make a faster growth than those fed a 2 per cent ration and hence be ready for the market earlier. As a saving of time lessens risk and also saves interest on investment, this is a factor to be considered. Figure 3 shows a representative hog from the lot getting no grain, and one each from lots getting 1 per cent, 2 per cent, and 3 per cent of corn in 1914. 
When a charge of $\$ 15$ per acre is made for the alfalfa pasture, the total cost per 100 pounds of gain was as follows: No-grain lot, $\$ 2.33$; 1 per cent corn lot, $\$ 3.29 ; 2$ per cent corn lot, $\$ 3.22 ; 2$ per cent barley lot, $\$ 3.14$; and the 3 per cent corn lot, $\$ 3.48$. The no-grain lot made gains for $\$ 1.15$ per hundredweight less than the 3 per cent corn lot did. It might appear from this that to pasture hogs on alfalfa without grain is the best practice, but this is not generally true, because of the much smaller returns of pork per acre.

Perhaps the most impressive thing shown in Table $\mathrm{V}$ is the amount paid for hay and its very rapid increase with the increase in the grain rations. The 2-year average yield of alfalfa hay from the check plats was 5.52 tons per acre. On this basis and assuming that the care of the hogs is equal to the cost of harvesting the hay, the nograin lot paid an equivalent of $\$ 8.16$; the 1 per cent grain lot paid $\$ 12.71$; the 2 per cent grain lots, an average of $\$ 22.67$, and the 3 per cent grain lot, $\$ 30.48$ a ton for alfalfa.

It seems certain that it will pay the farmer to feed hogs on alfalf: pasture at least 2 pounds of corn daily per 100 pounds of live weight. By so doing he will not only get a higher return from his alfalfa, but he may expect also to make a profit on the corn fed. According to these results, it requires less capital for the same net return where grain is fed than where no grain is fed. When a 3 per cent corn ration is fed with alfalfa pasture, 1 acre will produce as much pork as 6.5 acres of alfalfa without grain, or a saving of 5.5 acres of land. Again, when fed a 3 per cent corn ration with alfalfa pasture, 52 pigs will make as much pork as 156 pigs on alfalfa pasture alone.

\section{ALFALFA PASTURE FOR SOWS AND LITTERS.}

The following is a discussion of the results obtained by pasturing sows and their litters on alfalfa pasture. The first experiment began in the spring of 1914, as soon as the alfalfa was large enough to pasture, and continued 60 days. There were two sows and their pigs in each lot. During the first month and a half the quarter-acre plat furnished plenty of pasture, but after that time the pigs were so large that the pasture could not carry them all. When the pigs were large enough to wean, one or both of the sows were removed to prevent overpasturing.

The sows and pigs were fed daily approximately 2 pounds of corn for each 100 pounds of the weight of both sows and pigs. At first the grain was fed to the sows only, but later, when the pigs began to eat, they were fed separately. A small opening was made in the dividing fence, so that the pigs could go from one half of the pasture to the other. Both sows and pigs were fed twice daily, morning and evening. There are two ways of looking at the results of these 
experiments. One is to charge the pigs with only the feed and the other is to charge the pigs with both feed and the loss in weight of the sows. The second method is used here.

In 1914 two sows and 14 pigs were put on the alfalfa pasture plat on May 4. On this date the two sows weighed a total of 702 pounds and the 14 pigs a total of 164 pounds. The experiment closed on July 3. At this date one sow still remained on the plat, while the other one had been taken off on June 19. The final weight of the two sows was 603 pounds, or 99 pounds less than the initial weight. The 14 pigs weighed a total of 636 pounds. They had increased in weight 472 pounds in 60 days. The total initial weight of the sows and pigs was 866 and their total final weight 1,239 pounds, or a total increase of 373 pounds for the lot. The lot was fed 1,176 pounds of corn. The 373 pounds gain at $\$ 7$ per hundredweight is worth $\$ 26.11$. Deducting from this the cost of 1,176 pounds of corn at $\$ 1.07$ per hundredweight, or $\$ 12.58$, leaves a return of $\$ 13.53$ for one-fourth acre of alfalfa pasture for 60 days, or a daily return of 90 cents per acre. The sows and pigs ate 3.02 pounds of corn for each pound of net gain. With corn at $\$ 1.07$ per hundredweight and alfalfa pasture at $\$ 7$ an acre for 60 days, 100 pounds of gain cost $\$ 3.83$. This lot. paid the equivalent of $\$ 19.02$ a ton for alfalfa hay. A tabulated statement of this lot is given in the first column of Tables VI and VII.

In the 1915 tests, which began April 27 and ended June 26, there were three lots of two sows and litters each. One lot was fed ground barley and the other two lots were fed corn. They were fed grain at the rate of about 2 pounds daily for each 100 pounds of live weight. In two of the lots old sows were used and in the other gilts were used. The total initial weight of lot 6 , which received ground barley, was 760 pounds. The sows weighed 702 and the 17 pigs 58 pounds. One sow was taken off on June 9. The other remained until the close of the experiment. The total final weight was 1,178 pounds, or a total gain of 418 pounds. The sows lost 28 pounds and the pigs gained 446 pounds. A total of 982 pounds of ground barley was fed to this lot. From each 100 pounds of grain fed this lot produced 42.5 pounds of gain. After paying $\$ 1$ per hundredweight for the barley fed, the lot still paid at the rate of $\$ 1.30$ daily for an acre of alfalfa pasture. In lot 7, which was fed corn, the initial weight of the two sows was 873 pounds and of the 15 pigs 83 pounds, or a total of 956 pounds. The old sows were taken off the plat on June 9. At this date they weighed 780 pounds, or 93 pounds less than they did when the experiment began. The final weight of the pigs was 574 pounds, their increase being 491 pounds. The total increase in weight of the lot was 398 pounds. 
This lot was fed 1,098 pounds of corn. For each 100 pounds of corn fed this lot gained 36.2 pounds. The daily net return per acre of pasture was $\$ 1.09$. In lot 8 , which also received corn, the sows were gilts and were much lighter than the old sows in the other two lots. At the beginning of the experiment the two sows weighed 468 pounds, and when taken off the plat on June 9 they weighed 430 pounds, a loss of 38 pounds. The initial weight of the 15 pigs was 118 pounds and the final weight 541 pounds. The total gain of the lot was 385 pounds. While on pasture this lot was fed 881 pounds of corn, the lot producing 43.8 pounds of gain per 100 pounds of grain. On an acre basis, the daily net return for pasture was $\$ 1.17$.

The initial and final weights for both sows and pigs, with their loss or gain, and the amount of grain fed for the 1914 lot and the three 1915 lots are given in Table VI.

TABLE VI.-Weights of the sows and pigs and the amount of grain fed while on one-fourth of an acre of alfalfa pasture for 60 days, at the scottsbluff Experiment Farm in 1914 and 1915.

\begin{tabular}{|c|c|c|c|c|}
\hline \multirow[b]{2}{*}{ Items of comparison. } & 1914 & \multicolumn{3}{|c|}{1915} \\
\hline & Corn. & $\begin{array}{c}\text { Lot } 6, \\
2 \text { per cent } \\
\text { barley. }\end{array}$ & $\begin{array}{l}\text { Lot } 7, \\
2 \text { per cent } \\
\text { corn. }\end{array}$ & $\begin{array}{l}\text { Lot } 8, \\
2 \text { per cent } \\
\text { corn. }\end{array}$ \\
\hline Number of sows.. & 2 & 2 & 2 & 2 \\
\hline Number of pigs ............. & 14 & 17 & 15 & 15 \\
\hline $\begin{array}{l}\text { Initial weight of sows } \ldots \ldots \ldots \ldots \\
\text { Initial weight of pigs }\end{array}$ & 702 & $\begin{array}{r}702 \\
59\end{array}$ & 873 & 468 \\
\hline 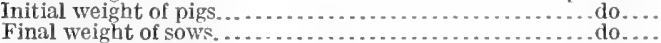 & $\begin{array}{l}161 \\
603\end{array}$ & $\begin{array}{r}58 \\
674\end{array}$ & $\begin{array}{r}83 \\
780\end{array}$ & $\begin{array}{l}118 \\
430\end{array}$ \\
\hline Final weight of pigs..... & 636 & 504 & 574 & 541 \\
\hline 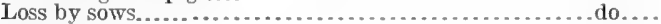 & 99 & 28 & 93 & 38 \\
\hline 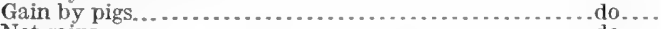 & 472 & 446 & 491 & 423 \\
\hline Net gains...... & 373 & 418 & 398 & 385 \\
\hline Grain fed....... & 1,176 & 982 & 1,093 & 884 \\
\hline
\end{tabular}

As shown in Table VI, the pigs used in 1914 were much larger than those used in 1915 , the former being older than the latter. If the lot had not been charged with the loss in weight of the sows, the results would have been still more farorable, especially in the 1914 lot and in lot 7. In these two lots, for some reason, the sows lost much more than in the other two. lots. More complete data obtained from pasturing sows and their litters on alfalfa in 1914 and 1915 are given in Table VII, in which the results have been computed to an acre basis.

As shown in Table VII, the net returns were higher in 1915 than in 1914. The arerage of the four lots shows that it required 2.62 pounds of grain with alfalfa pasture to produce 1 pound of gain, or for every 100 pounds of grain fed the sows and pigs gained 38.2 pounds. The average net return per acre of alfalfa pasture for 60 days was $\$ 66.8 t$, or a daily net return of $\$ 1.11$. The lowest net return for the pasture was $\$ 54.11$ and the highest $\$ 7 \pi .76$. This highest net return was obtained from the lot fed ground barley. 
TABLE VII.--Results obtained by feeding sows and their litters on alfalfa pasture, supplemented with a 2 per cent ration of grain, at the Scottsbluff Experiment Farm in 1914 and 1915.

\begin{tabular}{|c|c|c|c|c|c|}
\hline \multirow[b]{2}{*}{ Items of comparison. } & \multirow{2}{*}{$\begin{array}{c}1914, \\
2 \text { per cent } \\
\text { corn. }\end{array}$} & \multicolumn{3}{|c|}{1915} & \multirow{2}{*}{$\begin{array}{c}1914 \text { and } \\
1915, \\
\text { average } \\
\text { of } 4 \text { lots. }\end{array}$} \\
\hline & & $\begin{array}{l}\text { Lot } 6, \\
2 \text { per cent } \\
\text { barley. }\end{array}$ & $\begin{array}{c}\text { Lot } 7, \\
2 \text { per cent } \\
\text { corn. }\end{array}$ & $\begin{array}{c}\text { Lot } 8 \text {, } \\
\text { per cent } \\
\text { corn. }\end{array}$ & \\
\hline 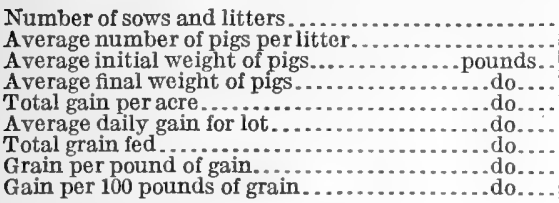 & $\begin{array}{r}8 \\
7 \\
11.71 \\
45.4 \\
1,492 \\
24.9 \\
4,704 \\
3.15 \\
31.7\end{array}$ & $\begin{array}{r}8 \\
8.5 \\
3.41 \\
29.6 \\
1,672 \\
27.9 \\
3,928 \\
2.35 \\
42.5\end{array}$ & $\begin{array}{r}7.5 \\
5.53 \\
38.2 \\
1,592 \\
26.5 \\
4,392 \\
2.76 \\
36.2\end{array}$ & $\begin{array}{r}7.5 \\
7.90 \\
36.1 \\
1,540 \\
25.7 \\
3,536 \\
2.28 \\
43.8\end{array}$ & $\begin{array}{r}8 \\
7.62 \\
6.95 \\
37.0 \\
1,574 \\
26.2 \\
4,140 \\
2.62 \\
38.2\end{array}$ \\
\hline $\begin{array}{l}\text { Financial statement: } \\
\text { Net returns per acre of pasture................ } \\
\text { Daily net returns per acre of pasture......... } \\
\text { Cost per } 100 \text { pounds of gain (pastureat } \$ 7 \text { peraere). } \\
\text { Equivalent paid for hay, per ton ............... }\end{array}$ & $\begin{array}{r}\$ 51.11 \\
.90 \\
3.83 \\
19.02\end{array}$ & $\begin{array}{r}\$ 77.76 \\
1.30 \\
2.76 \\
37.74\end{array}$ & $\begin{array}{r}\$ 65.52 \\
1.09 \\
3.32 \\
31.80\end{array}$ & $\begin{array}{r}\$ 69.97 \\
1.17 \\
2.91 \\
33.96\end{array}$ & $\begin{array}{r}\$ 66.84 \\
1.11 \\
3.21 \\
30.63\end{array}$ \\
\hline
\end{tabular}

If the sows and pigs are charged $\$ 7$ per acre for 60 days' use of alfalfa pasture, $\$ 1.07$ per hundredweight for corn, and $\$ 1$ per hundredweight for barley, each 100 pounds of gain cost an average of $\$ 3.21$. The gains on the 1914 lot cost $\$ 3.83$ per hundredweight, while the gains on lot 6 (barley) in 1915 cost only $\$ 2.76$.

The average yield of similar plats of alfalfa during these pasturing periods was 2.85 tons in 1914 and 2.06 tons in 1915. If it is assumed that the pastured plats would have yielded the same, the four lots paid an average of $\$ 30.63$ a ton for alfalfa hay and the hogs did the harvesting themselves. Moreover, by pasturing the alfalfa it may be assumed that the fertility of the soil was somewhat increased.

\section{HOGGING CORN.}

The experiments which have been conducted with different methods of hogging corn fall into two classes: (1) Those in which no supplement was fed with the corn and (2) those in which the hogs were provided with some nitrogenous feed while they were in the cornfield. Experiments in which no supplements were used have been conducted for four years and the others for two years.

\section{CORN WITHOUT SUPPLEMENTARY FEED.}

Each year in the irrigated crop-rotation field, a quarter-acre plat of corn in a 6-year rotation is fenced and the hogs are turned into it to harvest the crop. This experiment began in 1912 and has been continued each year. The hogs are turned into the corn when it is well "dented," usually about September 10. As no supplementary feed is supplied and as the weeds and volunteer alfalfa are kept down, the gains secured are made from corn alone. Each year since 1912 
the corn has been grown on land which had produced alfalfa the previous year. This explains the difference in yields, as will be indicated later.

In 1912 seven hogs were used in the test, one old sow weighing 384 pounds and six shotes with an average weight of 72 pounds. The hogs were on the plat 16 days. When removed the lot weighed 974 pounds, the total gain having been 157 pounds. The sow made a daily gain of 1.44 pounds, while each shote, weighing less than onefifth as much as the sow, gained 1.24 pounds per day. In other words, the sow made 0.6 per cent daily gain and the pigs made 1.51 per cent daily gain. The average yield of five similar quarter-acre plats of corn in the same field was 795 pounds. If it is assumed that the hogged plat yielded the same as this average, the hogs paid $\$ 1.38$ per hundredweight for the corn in the field.

Six thrifty shotes, averaging 92 pounds each, were used in 1913. These shotes had been on alfalfa pasture with a 2.3 per cent ration of corn during the summer. The shotes were on the corn plat 28 days. When they were taken off they weighed 800 pounds, having gained 253 pounds. The corn yield was estimated at 1,154 pounds. On this basis the hogs paid $\$ 1.53$ per hundredweight for the corn.

The six hogs used to harvest the corn plat in 1914 were thin and small. During the summer two had been on alfalfa pasture without grain and four on alfalfa pasture with a 1 per cent corn ration. Their total initial weight was 380 pounds and their total final weight was 642 pounds. The hogs were on the corn plat 49 days and gained 262 pounds. The yield of the corn plat was estimated at 1,142 pounds. On this basis the hogs paid $\$ 1.60$ per hundredweight for the corn in the field.

Three shotes, with a total initial weight of 224 pounds, were used in 1915. Their final weight, after they had been on the plat for 19 days, was 277 pounds, the gain being 53 pounds. This poor return was due to the fact that the corn plat was almost completely hailed out. The yield of the plat was estimated at 370 pounds. In this test, if the estimated yield is correct, it required 694 pounds of corn to produce 100 pounds of gain and this gain cost $\$ 7.43$.

The results of the four years' tests, computed to an acre basis, are given in Table VIII. These results are not strictly comparable, as there were two varying factors. The average initial weight of the hogs varied from 117 pounds in 1912 to 63 pounds in 1914, and the number of days that the hogs were on the corn varied from 16 in 1912 to 49 in 1914. Small shotes will make more gain than larger hogs from a given quantity of feed. Hogs that have just been taken from alfalfa pasture will make rery good gains for a short period on corn alone, but when fed corn alone for a long period the gains are not so good. In other words, 100 pounds of corn will make more 
gain on hogs the first week after the hogs are taken off alfalfa pasture than the same amount of corn will when fed to hogs that have been on corn alone for several weeks. As will be seen from Table VIII, these two variable factors were in direct opposition to each other; that is, the larger the hogs the shorter the feeding period. As the corn crop in 1915 was seriously affected by hail, the results of that year are not included in the average shown in Table VIII, but they are shown in the last column of the table as a matter of record.

TABLE VIII.-Results of hogging corn without supplementary feed at the Scottsbluff Experiment Farm in 1912, 1913, 1914, and 1915.

\begin{tabular}{|c|c|c|c|c|c|}
\hline Items of comparison. & 1912 & 1913 & 1914 & $\begin{array}{c}\text { 3-year } \\
\text { average. }\end{array}$ & 1915 \\
\hline 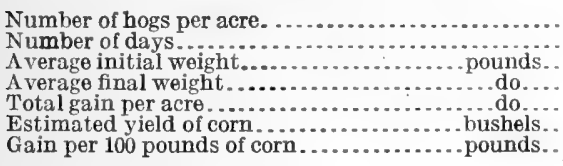 & $\begin{array}{r}28 \\
16 \\
117 \\
139 \\
628 \\
56.1 \\
20.0\end{array}$ & $\begin{array}{r}24 \\
28 \\
91 \\
133 \\
1,012 \\
82.6 \\
21.8\end{array}$ & $\begin{array}{r}24 \\
49 \\
63 \\
107 \\
1,048 \\
81.9 \\
22.6\end{array}$ & $\begin{array}{r}23 \\
31 \\
90 \\
126 \\
896 \\
76.87 \\
21.5 \\
\end{array}$ & $\begin{array}{r}12 \\
19 \\
75 \\
92 \\
212 \\
26.2 \\
14.5\end{array}$ \\
\hline 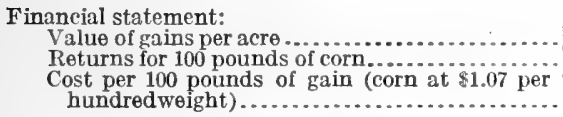 & $\begin{array}{r}\$ 42.96 \\
1.38 \\
5.36\end{array}$ & $\begin{array}{r}\$ 70.84 \\
1.53 \\
4.81\end{array}$ & $\begin{array}{r}\$ 73.36 \\
1.60 \\
4.67\end{array}$ & $\begin{array}{r}\$ 65.72 \\
1.50 \\
4.95\end{array}$ & $\begin{array}{r}\$ 14.84 \\
1.00 \\
7.43\end{array}$ \\
\hline
\end{tabular}

A short hogging period is objectionable from an experimental standpoint because there are more chances of error. For example, if the hogs are gaunt at either the initial or final meighing, 20 hogs on a corn plat for 1 week will give a larger error than 2 hogs on the same plat for 10 weeks. The mean weight of three consecutive days' weighing will not entirely eliminate this error, especially if the hogs are left on the corn plat too long and are gaunt at the final weighing. Just how much each of these factors influenced the results shown in Table VIII is uncertain. There is little doubt that the low returns per bushel of corn in 1912 were due to the fact that the large sow was in the lot. The low total gains and net returns per acre in 1912, however, were due largely to the low yield of corn, it having been estimated at 56.1 bushels per acre, as compared with 82.6 and 81.9 bushels, respectively, for the two succeeding years. In computing the cost of 100 pounds of gain, a charge of $\$ 1.07$ per hundredweight was made for the corn. The results show that this method of utilizing corn has much to recommend it.

\section{CORN WITH SUPPLEMENTARY FEED.}

To secure information regarding the ralue of tankage and of alfalfa pasture as supplements to corn when hogged off, an experi. ment was conducted in duplicate in 1914 and 1915. Six lots of hogs were used each year, as follows: Lots 1 and 2, hogged corn alone; lots 3 and 4, hogged corn and had access to an alfalfa field; and lots 
5 and 6 , hogged corn and had what tankage they would eat. The shotes used in this experiment had been in the alfalfa pasturing experiment and were very uniform in size, as will be seen from the weights given in Table IX.

Both years the cornfield to be hogged was divided into six separate fields of one-third acre each by a fence of 26 -inch hog wire between the corn rows. The cornfield used in 1914 was located on a break of high land, where in places the gravel came near the surface, causing some differences in the yield of the different plats. The plats used in 1915 were more uniform, but the corn, owing to hail and frost, was not as good as the corn that was hogged the year before.

Each year the yield of each plat was estimated by counting all the stalks of corn and harvesting systematically the corn from 100 stalks; that is to say, if a plat had a total of 3,400 stalks, the corn was harrested from every thirty-fourth stalk. The harvested corn was dried, weighed, and returned to the plat to be eaten by the hogs. The total weight was divided by 100 , to get the average yield per stalk harrested. This a verage weight was then multiplied by the total number of stalks on the plat in order to get the yield.

As the low-yielding plats became cleaned up, weighed quantities of corn were added, so that all the hogs would be kept on feed the same length of time. Enough corn was added as became necessary so that the hogs had corn before them all the time. When the last lot had cleaned up its plat the experiment was closed. In 1914 the hogs were in the corn plats from September 9 to November 25, a period of 77 days. The 1915 test began October 6 and closed Norember 30, covering a period of $\mathbf{5 5}$ days.

The hogs were watered twice a day. Lots 5 and 6 were fed tankage when they were watered, the tankage being fed as a thin slop. The plats used by lots 3 and 4 opened into an alfalfa pasture. The hog house was placed in the alfalfa field, so that the hogs would have to pass through the alfalfa in going to and from the cornfield. All weeds and volunteer alfalfa were removed from the plats where the hogs got corn alone or corn and tankage.

The results secured with the duplicate lots each year were relatively uniform. In no case were the gains cheaper or the quantity of corn required for 100 pounds of gain less in the corn lot than in the tankage lot, and in only one tankage lot were they cheaper than any pasture lot. One tankage lot in 1915, however, made slower gains than either of the pasture lots and slower than one of the corn lots; and one corn lot made faster gains than one of the pasture lots. With this exception, the results of the duplicate lots were relatively the same. In 1915 the hogs required more corn per 100 pounds of gain than was required in 1914 . This was probably due to the poorer quality of the corn in 1915 . The corn that was added to the 
plats in 1915 had also been badly damaged by hail. As the results from the 1914 experiment were almost identical with those of the 1915 experiment, only the 2 -year average will be discussed here.

Corn alone.-The corn hogged by the four lots receiving no supplementary feed was estimated as the equivalent of 1,091 pounds of shelled corn, and the equivalent of 209 pounds of shelled corn was added, making a total of 1,300 pounds of corn consumed. These lots made an arerage gain of 248 pounds. For each 100 pounds of gain they consumed 524 pounds of corn, valued at $\$ 5.61$.

Corn plus alfalfa pasture.-At the time of year when corn is hogged alfalfa makes slow growth. Before the experiment closed, the alfalfa was furnishing but little feed. The hogs receiving alfalfa as a supplementary ration had access to about the same area of alfalfa pasture as was occupied by the corn plat. They were charged at the rate of $\$ 1$ an acre for the use of the alfalfa pasture after the last cutting. The lots made a total gain of 310 pounds. It was estimated that they hogged 1,163 pounds, and 220 pounds were added to the plat, making an equivalent of 1,383 pounds of shelled corn consumed. It required 446 pounds of corn, supplemented by alfalfa pasture, to make 100 pounds of gain, which cost $\$ 4.88$.

Corn and tankage.-The lot on corn and tankage made $3+3$ pounds of gain. It was estimated that the corn plat yielded 1,038 pounds, and 349 pounds of corn were added, making a total of 1,387 pounds consumed. In addition to the corn, the lot was fed 100 pounds of tankage. The tankage cost $\$ 3.20$ per hundredweight, delivered at Mitchell, Nebr., in 500-pound lots. For each 100 pounds of gain made, the hogs ate 405 pounds of corn and 29 pounds of tankage. The gains cost $\$ 5.26$ per 100 pounds.

A summary of the two years' results of these experiments, calculated to an acre basis, is given in Table IX.

TABLE IX.-Results of hogging coln, with supplementary feed, at the Scottsbluff Experiment Farm in 1914 and 1915.

\begin{tabular}{|c|c|c|c|}
\hline Items of comparison. & $\begin{array}{l}\text { Corn } \\
\text { only. }\end{array}$ & $\begin{array}{c}\text { Corn and } \\
\text { alfalfa } \\
\text { pasture. }\end{array}$ & $\begin{array}{l}\text { Corn and } \\
\text { tankage. }\end{array}$ \\
\hline  & $\begin{array}{r}4 \\
9 \\
66 \\
81.7 \\
164.4 \\
1.25 \\
744 \\
3,900\end{array}$ & $\begin{array}{r}4 \\
9 \\
66 \\
81.7 \\
185.0 \\
1.57 \\
930 \\
4,149 \\
\end{array}$ & $\begin{array}{r}4 \\
9 \\
66 \\
81.0 \\
195.3 \\
1.73 \\
1,029 \\
4,161\end{array}$ \\
\hline 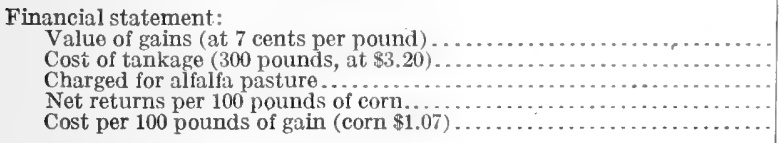 & $\begin{array}{r}\$ 52.08 \\
\cdots \\
1.34 \\
5.61\end{array}$ & ( 1.10 & $\begin{array}{r}872.03 \\
9.60 \\
\text { 1. } 50 \\
5.26\end{array}$ \\
\hline
\end{tabular}


The data given in Table IX are the averages of four lots in each case and are calculated to an acre basis. The hogs were on the experiment 77 days in 1914 and 55 days in 1915, or an average for the two seasons of 66 days. The average initial weight of the shotes in the different lots was 81 pounds, and the average final weight was 164.4 pounds for the corn-alone lot, 185 pounds for the pasture lot, and 195.3 pounds for the tankage lot, or $1.25,1.57$, and 1.73 pounds of daily gains, respectively. The tankage lot made 38 per cent faster gains than the corn-alone lot and 10 per cent faster than the pasture lot. The total gain, on an acre basis, was 744 pounds where the hogs received only corn, 930 pounds where they had access to alfalfa pasture, and 1,029 pounds when fed 300 pounds of tankage in connection with the corn. The net return per 100 pounds of corn consumed was ' $\$ 1.34$ where corn was fed alone, $\$ 1.55$ where the hogs had access to alfalfa pasture, and $\$ 1.50$ when they were fed tankage. A 100 -pound gain cost $\$ 5.61$ in the corn lot, $\$ 4.88$ in the pasture lot, and $\$ 5.26$ in the tankage lot.

From the results of these tests it appears that it would be better to buy tankage at $\$ 3.20$ per hundredweight and feed it to hogs in connection with hogged-off corn than not to supplement the corn, but when the hogs can have access to alfalfa pasture it is doubtful whether it would pay to feed tankage.

The chief advantage of hogging corn is that the farmer is spared the expense of harvesting the crop, hauling the manure back to the land, and feeding the corn to the hogs. A disadvantage is the cost of fencing. It seems certain that hogs will make as many pounds of gain from a bushel of corn in the field as they will if the corn is harrested and fed in a dry lot. The question for the farmer to decide, then, is whether it is cheaper to harvest the crop and feed the hogs in a dry lot or to fence the corn and let the hogs themselves harvest it.

\section{SUMMARY .}

Because of the relatively small capital and short time required to get a start in the swine industry and because of the high efficiency of hogs in utilizing certain field crops, swine production is a specially promising industry for irrigation farmers. In order to secure information regarding methods of utilizing hogs in the disposal of certain field crops produced on irrigated lands, experiments were conducted at the Scottsbluff Experiment Farm on the North Platte Reclamation Project in 1912, 1913, 1914, and 1915.

In three years' experiments, including eight lots of hogs, in which alfalfa pasture was supplemented with a 2 per cent ration of corn, an average gain of 3,181 pounds per season was made from an acre of alfalfa pasture and 7,844 pounds of corn. It required an a verage 
of 2.47 pounds of corn in addition to alfalfa pasture to produce 1 pound of pork. If the gains are valued at 7 cents a pound and corn at 60 cents a bushel, or $\$ 1.07$ a hundredweight, the average annual return was $\$ 138.75$ per acre of alfalfa pasture. If the corn fed is valued at 60 cents a bushel and the alfalfa pasture at $\$ 15$ an acre the average cost of 100 pounds of gain was $\$ 3.11$. If the average yield of the alfalfa plats in the same field is assumed to represent the yield of the pastured plats the hogs paid an equivalent of $\$ 25.13$ per ton of hay.

In two years' experiments with alfalfa pasture, with and without supplemental feed, an average annual return of $\$ 45.08$ per acre was secured where no supplement was used, as compared with $\$ 70.20$ where a 1 per cent ration of corn was used-\$128.49 from a 2 per cent ration of corn - $\$ 121.96$ from a 2 per cent ration of barley, and $\$ 168.25$ from a 3 per cent ration of corn. The rate of gain and the carrying capacity of the pasture increased with the quantity of grain fed. Ground barley appeared to be as good, pound for pound, as shelled corn as a feed for hogs on alfalfa pasture.

Sows and pigs on alfalfa pasture, with a 2 per cent ration of grain, made an arerage gain of 1,574 pounds per acre of alfalfa pasture from May 1 to July 1 , or a net return of $\$ 66.84$ per acre. When corn was used the return varied from $\$ 54.11$ to $\$ 69.97$ per acre, and when barley was used the return was $\$ 77.76$ per acre.

In three years' experiments, hogging corn without supplementary feed produced an average of 896 pounds of gain, worth $\$ 65.72$ per acre, or $\$ 1.50$ per hundredweight of the estimated vield of corn.

In two years' experiments, hogging corn without supplementary feed produced an arerage of 744 pounds of gain, worth $\$ 52.08$ per acre, as compared with 930 pounds of gain, worth $\$ 65.10$, where the hogs had access to alfalfa pasture, and 1,029 pounds of gain, worth $\$ 72.03$, where the hogs were fed tankage in addition to the corn. Where no supplementary feed was used the hogs paid $\$ 1.34$ per, hundredweight for the estimated yield of corn, as compared with $\$ 1.55$ per hundredweight where the hogs had access to alfalfa pasture and $\$ 1.50$ per hundredweight where tankage was used. The use of either alfalfa or tankage resulted in more rapid and cheaper gains than were secured where no supplementary feed was used. 


\section{PUBLICATIONS OF THE UNITED STATES DEPARTMENT OF AGRI- CULTURE RELATING TO IRRIGATION.}

\section{AVAILABLE FOR FREE DISTRIBUTION.}

Profits in Farming on Irrigated Areas in Utah Lake Valley. (Department Bulletin 117.)

Experiments with Crops under Fall Irrigation at the Scottsbluff IReclamation Project Experiment Farm. (Department Bulletin 133.)

Experiments in the Production of Crops on Alkali Land on the Huntley Reclamation Project, Montana. (Department Bulletin 135.)

Establishing the Swine Industry on the North Platte Reclamation Project. (D. R. P. 1.)

Irrigated Pastures for Northern Reclamation Projects. (D. R. P. 2.)

Sugar-Beet Growing Under Irrigation. (Farmers' Bulletin 567.)

The Work of the Huntley Reclamation Project Experiment Farm in 1915. (W. I. A. S.)

The Work of the Belle Fourche Reclamation Project Experiment Farm in 1915. (W. I. A. 9.)

The Work of the Scottsbluff Reclamation Project Experiment Farm in 1915. (T. I. A. 11.)

The Work of the Yuma Reclamation Project Experiment Farm in 1915. (W. I. A. 12.)

The Work of the Truckee-Carson Reclamation Project Experiment Farm in 1915. (W. I. A. 13.)

The Settlement of Irrigated Lands. (Yearbook Separate 608.)

Agriculture on Gorernment Reclamation Projects. (Yearbook Separate 690.)

FOR SALE BY THE SUPERINTENDENT OF DOCUMENTS, GOVERNMENT PRINTING OFFICE.

Progress Report of Cooperative Irrigation Experiments at California University Farm, Davis, Cail., 1909-1912. (Department Bulletin 10.) I'rice, 5 cents.

Irrigation of Alfalfa. (Farmers' Bulletin 373.) Price, 5) cents.

Potato Culture on Irrigated Farms of the West. (Farmers' Bulletin 386.) I'rice, 5 cents.

Irrigation of Sugar Beets. (Farmers' Bulletin 392.) Price, 5 cents.

Irrigation of Grain. (Farmers' Bulletin 399.) Price, 5 cents.

Timothy Production on Irrigated Land in the Northwestern States. (Farmers' Bulletin 502.) Price, 5 cents.

Irrigation Practice among Fruit frowers on the Pacific Coast. (Office of Experiment stations Bulletin 10S.) Price, 15 cents.

Report of Irrigation Investigations in Utah. (Office of Experiment Stations Bulletin 124.) Price $\$ 1.10$, cloth only.

Irrigation in Wyoming. (Ofice of Experiment Stations Bulletin 205.) Price, 15 cents.

Irrigation in the Sacramento Valley, California. (Oflice of Experiment Stations Bulletin 207.) Price, 15 cents.

Irrigation in Oregon. (Office of Experiment Stations Bulletin 209.) Price, 15 cents. 
Irrigition in South Dakota. (Office of Experiment Stations Bulletin 210.) I'rice, 10 cents.

Irrigation in the State of Washington. (Office of Experiment Stations Bulletin 214.) Price, 10 cents.

Irrigation in New Mexico. (Office of Experiment Stations Bulletin 215.) Price, 15 cents.

Irrigation in Idaho. (Office of Experiment Stations Bulletin 216.) Price, 15 cents.

Irrigation in Colorado. (Office of Experiment Stations Bulletin 218.) I'rice, 15 cents.

Irrigation in North Dakota. (Office of Experiment Stations Bulletin 219.) Price, 10 cents.

Irrigation in Arizona. (Office of Experiment Stations Bulletin 235.) Price, 20 cents.

Irrigation in California. (Office of Experiment Stations Bulletin 237.) Price, 10 cents.

Investigations of Irrigation Practice in Oregon. (Office of Experiment Stations Circular 67.) Price, 5 cents.

Progress Report on Experiments in Supplemental Irrigation with Small Water Supplies at Cheyenne and Newcastle, Wyo., 1905-1908. (Office of Experiment Stations Circular 92.) Price. 5 cents.

Experiments in Supplemental Irrigation with Small Water Supplies at Cheyenne, Wyo., in 1909. (Oftice of Experiment stations (ircular 95.) I'rice, 5 cents.

Agricuitural Observations on the Truckee-Carson Irrigation I'roject. (Burealu of Plant Industry Circular 78.) Price, 5 cents.

Suggestions to Potato Growers on Irrigated Lands. (Bureau of Plant Industry Circular 90.) Price, 5 cents.

\footnotetext{
ADDITIONAL COPIES

OF THIS PUBLICATION MAY BE PROCURED FROM

THE SUPERINTENDENT OF DOCUMENTS

GOVERNMENT PRINTING OFFICE

WASHINGTON, D. C.

$\triangle T$

5 CENTS PER COPY
} 




\section{Syracuse, N. Y.
Pat. Jan. 21, 1908}
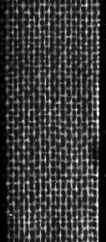
